\title{
o pequeno, o grande e o pequeno Entrevista com Giovanni Levi
}

\author{
Small, large, and small \\ Interview with Giovanni Levi
}

Giovanni Levi

\begin{abstract}
Entrevista realizada em Roma, em 16 de fevereiro de 1990. Com pauta preparada por Guido Crainz, Gino Massullo e Giacomina Nenci, foi publicada no número 10 de Meridiana, em 1990. Transcrição e revisão do original a cargo de Giuseppe Croce e Antonella Pagano. ${ }^{1}$
\end{abstract}

Giovanni Levi (levi@unive.it), professor emérito da Università Ca'Foscari de Veneza, nasceu em Milão em 1939 e estudou em Turim com Walter Maturi, Franco Venturi e Aldo Garosci. Desenvolveu sua atividade de pesquisa em Turim, publicando numerosos artigos sobre a história da família, sobre a agricultura e sobre demografia no Piemonte nos séculos XVII e XVIII. Entre seus livros destacam-se Centro e periferia di uno stato assoluto (Levi, 1985) e L'eredità immateriale (A herança imaterial, Levi, 2000). Particularmente rico foi seu ativismo cultural: como consultor e editor da casa Rosenberg \& Sellier; como fundador e diretor, com Carlo Ginzburg, da coleção Microstoria, da editora Einaudi; e como redator e animador, por muitos anos, de Quaderni storici.
Giovanni Levi (levi@unive.it), professor emeritus at the Università Ca'Foscari of Venice, was born in Milan in 1939 and studied in Turin with Walter Maturi, Franco Venturi and Aldo Garosci. He developed his researches in Turin, publishing numerous articles on the history of the family, on agriculture and on demography in Piedmont in the 17th and 18th centuries. Centro e periferia di uno stato assoluto (Levi, 1985) and L'eredità immateriale (Levi, 1985a) are among his books. Particularly remarkable was his cultural activism: as consultant and editor of the Rosenberg \& Sellier house; as founder and director, with Carlo Ginzburg, of the Microstoria collection, from Einaudi; and as editor and animator, for many years, of Quaderni storici. 


\section{Partamos da adolescência e da sua formação, do momento em que tomaram forma os primeiros projetos, as primeiras questões culturais. Onde estudou? Com quem? O que lhe interessava?}

$\mathrm{Na}$ realidade, estou totalmente despreparado para responder a essa pergunta, e devo dizer que nunca pensei no momento da minha formação. Certamente não se deu, a não ser uma parte diminuta, no âmbito universitário. Penso que contou muito o fato de eu vir de uma família de intelectuais pertencentes a uma minoria religiosa e, para nosso azar, uma minoria também política. Creio que pertencer a um grupo minoritário seja algo muito útil para arranjar problemas, para afrontar o mundo numa perspectiva em parte vitimizadora e em parte narcisista. Mas, ainda assim, levanta uma dificuldade positiva no relacionamento com o mundo.

Frequentei o liceu [ensino médio] em Gênova, cidade que adoro. $\mathrm{Na}$ escola era o último da classe: portanto, não posso dizer que tenha sido para mim um período de extraordinária formação. Foi, antes, um período entediante no relacionamento com os colegas, a tal ponto que, mesmo quando criança - tinha apenas 14 anos - solicitei inscrever-me na Federazione Giovanile Comunisti Italiani [FGCI, Federação Juvenil dos Comunistas Italianos], mas fui recusado por ser o último da classe.

Todavia, até mesmo esse período genovês contou muito, porque, enquanto eu estava no ginásio, meu pai, que era diretor de uma fábrica do Istituto per la Ricostruzione Industriale (IRI), foi, em 1956, demitido sob a acusação de ser espião da Tchecoslováquia. Essa situação familiar difícil, penso, contribuiu para me aproximar, precocemente, do problema político.

Em 1958 fui para a universidade em Turim, sem motivo, talvez o único pretexto fosse estar enamorado por uma menina, então quase uma criança, que depois se tornou minha mulher. Talvez eu também tenha feito isso para sair de casa; além do mais, ocorria em Turim o renascimento de certas experiências políticas muito atraentes para mim. Reapareciam as lutas operárias na Fiat: entre 1958 e 1963 interrompeu-se o longo e dramático período da história sindical na Fiat; o sindicato renasceu e eu, naquele período, me divertia muito mais na luta política do que no trabalho universitário. Penso que isso contou muito na minha formação: não fui protagonista da experiência dos Quaderni rossi, mas eu a vivi muito de perto. Tive a mesma experiência da minha geração na cidade em todo aquele período: aliás, convivi alguns meses com Danilo Dolci, mas briguei ferozmente com ele por causa da superficialidade com que eram coletados os dados no decurso de um trabalho que depois levaria ao livro Spreco (Dolci, 1962). Creio que, em minha formação, tudo isso tenha contado 
muito, e muito pouco pesou, inversamente, a minha atividade universitária, que desenvolvi especialmente com Franco Venturi e Walter Maturi, este um velho e simpático professor napolitano.

Pouco tempo depois me formei, com Aldo Garosci e Siro Lombardini, com uma tese sobre Alberto De Stefani, isto é, sobre a política econômica italiana no primeiro período do fascismo. Passei muitos meses em Roma, porque lá vivia esse monstruoso personagem que é definido na Enciclopédia Treccani como aquele que "libertou da tirania dos vermelhos o porto de Gênova". Morava em uma casa chinesa com uma filha chinesa, e quando fui procurá-lo me disse: "agora vou apresentá-lo à minha filha chinesa". Me tratava tranquilamente por você, era um senhor gigantesco e eu era pequenino, não me mostrava os documentos do seu arquivo, mas me exibia filhos chineses, móveis chineses, relações financeiras sobre a China; havia sido consultor econômico de Chiang Kai-Shek. Era em suma uma personagem interessante, inclusive para a história da difusão do fascismo no mundo.

Eu gostaria de sublinhar, porém, que Aldo Garosci foi decisivo na minha formação. Era uma personagem muito distante do meu modo de ver a política. Parecia não entender nada do que se passava, mas tinha algo de fascinante: era como se existisse um buraco de 20 anos na sua experiência - discutia, por exemplo, o "caso Tambroni" como se houvesse ocorrido em 1945 e não em 1960 -, e isso me parecia extraordinariamente fascinante porque introduzia elementos imprevistos e fantasiosos nas suas análises, talvez inconcebíveis, não obstante - não sei dizer por quê - provocativamente problemáticos, imprevistos. Forçavam uma revisão dos problemas: ao menos para se perguntar por que alguém podia ler de modo assim inusitado e diverso. Creio ter realmente aprendido muito com esse relacionamento.

Penso ter sido muito menos influenciado por Franco Venturi. Embora fosse um grandíssimo mestre, um grandíssimo historiador, sua relação com os estudantes denunciava certo aristocratismo: entrava na sala, abria um caderno em que havia escrito no dia anterior, lia, depois fechava o caderno e saía.

Com ele, a relação não passava jamais pela didática; era fascinante, entretanto, quando se podia pegá-lo na biblioteca ou na reunião da Rivista storica italiana, mas do ponto de vista didático penso que Franco Venturi não foi para mim um mestre importante. Garosci e Maturi marcaram muito mais a minha formação.

Depois, creio que contaram bastante várias pessoas que se tornaram minhas amigas, com as quais cresci: Mauro Adamoli, meu companheiro de jogos e de aventuras em Gênova, a quem devo boa parte do gosto pelo paradoxo; 
Edoardo Grendi, genovês que ensinava em Turim e que foi talvez o que mais me ensinou sobre quais são os problemas históricos; Carlo Ginzburg: sempre me pareceu que os meus segundos nomes (Carlo Nello, os nomes dos irmãos Rosselli) fossem os mesmos dele. No entanto nos conhecemos jogando futebol, apesar do longo entrelaçamento familiar comum.

\section{Como se iniciou a sua carreira de estudioso? Como colocou em foco a opção histórica, como nasceu e se desenvolveu uma relação privilegiada com os ambientes históricos europeus?}

Comecei a fazer história em 1966. A primeira coisa que escrevi, exatamente em 1966, foi uma proposta para a Rivista storica italiana, logo rejeitada por Leo Valiani, ainda na forma de esboço, com uma anotação: "isto é política, não é história". Era uma resenha sobre Clough.

Eu tive, entretanto, um começo muito ligado à Rivista storica italiana e a Venturi. Meus primeiros textos foram redigidos pensando que a minha referência "corporativa" devesse ser especialmente Franco Venturi e a escola da esquerda idealista. As primeiras coisas que escrevi, portanto, saíram nessa revista. O último texto que escrevi para ela foi um artigo que, por três anos, não ousei publicar porque me parecia de um tédio mortal e que, entretanto, foi depois apreciado. Hoje gosto muito desse texto, embora seja um artigo mortífero sobre a história da estatística, a estatística do século XVIII. Até então eu tinha uma imagem muito "corporativa" do ofício do historiador, ou seja, pensava que os leitores dos livros e dos artigos de história devessem ser outros historiadores profissionais. Imaginava um grupo de leitura grande com 52 pessoas: 52 me dava a sensação de grande relacionamento com o público.

Uma das coisas que mais discuti com Carlo Ginzburg foi precisamente esta, quer dizer, que relação travamos com o leitor por meio da escrita, que tipo de leitor se imagina. Carlo Ginzburg sustentava que é necessário escrever pensando haver um milhão de leitores: o conflito era entre os cinco leitores e um milhão de leitores, e essa discussão me tem de todo modo ensinado que entre cinco e um milhão de leitores há algo no meio que é possível de alguma forma imaginar.

O caminho do meio está aí: imaginar que se possa pensar uma atividade científica e de pesquisa histórica que encontre ressonância em um público diferente do companheiro que está ao lado. 
Antes de chegar à escolha pela micro-história houve uma fase de história econômica...

Como eu disse, fiz uma monografia - que não publiquei, mas me custou muito esforço - sobre a economia fascista entre 1922 e 1925 . Trata-se de uma pesquisa absolutamente não micro-histórica, inspirada essencialmente em Salvemini. Em Gênova, eu havia colocado em ordem o arquivo de Camillo Berneri, o dirigente anarquista assassinado pelos stalinistas em 1937 em Barcelona. Camillo Berneri era um aliado de Salvemini e, quando Salvemini escreveu um artigo sobre economia fascista entre 1922 e 1925, teve Camillo Berneri como assistente: Salvemini mandava Camillo e Giovanna Berneri à biblioteca e dizia: "parece que Sturzo disse que...".

Enquanto reordenava esse arquivo, eu havia lido toda a correspondência entre Salvemini e a família Berneri, que era extraordinariamente fascinante e interessante.

Quando terminei essa tese, não trabalhei mais: encontrei muita dificuldade de acesso, seja aos papéis do arquivo central, seja aos de De Stefani. Esperei que De Stefani morresse, mas então eu já não me interessava mais por isso.

Era uma história bem macro: trabalhei com balanços, previsões..., muito embora sua origem fosse a história muito dramática e comovente de Camillo Berneri.

Depois trabalhei com salários, mas estava realmente tateando. Sempre me fascinou montar séries e manusear um documento único - "fazer cantar um documento". Por exemplo, as séries salariais exercem sobre mim o maior fascínio.

\section{Como era a sua caixa de ferramentas quando estudou as séries salariais?}

$\mathrm{Eu}$ me formei com Lombardini e Garosci, e logo assumi a atividade de economista prático. Fora da universidade, encontrei emprego em uma empresa que realizava pesquisas econômico-sociais. Trabalhei aí entre 1964 e 1965, e foi algo importante na minha formação, porque recebi um duro tratamento de educação com vistas à escrita e ao manuseio de materiais quantitativos.

Essa empresa era dirigida por dois personagens: Cominotti e Garavini (este, irmão de um Garavini mais célebre; Cominotti é ainda um personagem em haver: parece que foi conselheiro comunal pelo Partido Republicano, mas de origem comunista). Estando lá, fiz algumas coisas que apreciei bastante e que ainda gostaria muito de fazer: pesquisas sobre pequenos industriais etc. Creio que essa experiência influenciou também na escrita, porque Garavini 
tinha a mania de considerar deletéria a minha formação literária e me obrigava a reescrever qualquer coisa de modo que tudo se iniciasse com a linha "o escopo da seguinte pesquisa...”. Isso decerto me condicionou: penso que muitos dos meus artigos iniciam com "o escopo da seguinte pesquisa".

Naquele período, aprendi a usar uma correlação, um índice, e também uma máquina enorme, que era um estranho leitor de cartões, gigantesco, agora inimaginável: fazia muito barulho, relia, classificava etc. Desde então, tenho sentido o grande fascínio de manipular os números, paixão que possuía precedentemente: as ferramentas de que dispunha foram elaboradas enquanto desempenhava essa atividade, fazendo em particular o plano intermunicipal de Savona.

Penso em três coisas, três pares opostos. Primeiro: azionismo-marxismo, a saber, um caldo de cultura azionista abundantíssimo, como vimos, mas também um contato com coletivos do movimento operário que, eu presumo, o levaram a acertar os ponteiros com certa cultura difusa daquele momento (você citou agora há pouco os Quaderni rossi, por exemplo). ${ }^{2}$ Segundo: as relações entre a história econômica e a história política. A corda da qual você é um fio é mais da formação de história política, dizem, e me parece que deve ser mais bem explicada essa passagem sobre os dados, certamente motivada por uma série de contingências. Terceiro: história moderna-história contemporânea, ou seja, os mestres espalhados sobre esse arco cronológico e ainda - me parece - suas tentativas, distribuídas nesses vários segmentos.

Enquanto você falava veio-me à mente que talvez devesse dizer outra coisa. Penso que tenha havido outro elemento da minha formação muitíssimo relevante nas minhas relações com a micro-história: é impressionante como eu havia tido certas experiências que não me surpreenderam, experiências que recontadas pelos historiadores são surpreendentes - por exemplo a guerra, o fascismo, o antissemitismo etc. -, enquanto eu, durante a guerra, brincava com os fascistas e os partigiani. Quando completei 7 anos, terminou a guerra e minha mãe me presenteou com Pinóquio, acompanhado da dedicatória "a Giovanni, para que terminada a sua gloriosa carreira de partigiano, possa finalmente voltar a ler". Eu estava exilado - me chamava Giovanni Cardone em uma pequena cidade onde as crianças do local brincavam de fascistas e partigiani porque num mês eram os fascistas que comandavam e, no mês seguinte, os partigiani. $\mathrm{O}$ fato de eu me recordar do período da guerra, um período sem dúvida dramático - e vi algumas coisas dramáticas -, como um período absolutamente delicioso, ao qual voltaria com entusiasmo, foi sempre 
um problema. Como foi sempre um problema que, em 1945, chegando a Turim, meus pais sentiram-se no dever de me inscrever na escola judaica porque éramos poucos judeus e era preciso fazer ver que ainda existíamos. A escola judaica, em 1945, teria espantado qualquer um, mas eu, ao contrário, não tinha meios de comparação e não me espantei... Havia um rabino que ao nos olhar chorava, todas as manhãs tínhamos uma hora de lição de hebraico em que ele nos olhava, a nós, as crianças - seus filhos haviam sido mortos - e chorava; e depois de uma hora saía. Durante o ano de 1945 e até o início de 1946 , fomos tomados do feroz sadismo dos filmes que os americanos haviam rodado nos campos de concentração. Ainda não montados, eram 8 horas de tratores a espalhar cadáveres. Tive um choque que amadureceu muito lentamente, tanto que ainda hoje não me arrisco a encarar aquelas imagens, nem a ler livros sobre campos de concentração. Mas naquele instante pensei que fosse natural colocarem as crianças para ver tratores empurrando cadáveres. Essa crença foi muito importante para mim, não só em si, em relação ao fato de eu ser judeu, mas também no modo de colocar os problemas: o que é que nos deixa sem chão e o que é que não nos deixa desorientados (e por quê)? E que relação há entre a nossa capacidade de considerar uma coisa bela ou ruim e o fato de que depois a consideramos realmente bela ou ruim?

Fechado este parêntese, passemos ao marxismo. Sim, os anos de 1958 a 1963 foram um período apaixonante; um período grandioso no sentido de que a luta sindical renascia e transmitia realmente a sensação de um mundo que se estava transformando. Minha participação, como a de outros estudantes, era muito ingênua, embora discutíssemos muito. Lembro-me de que marchávamos todas as manhãs diante da Lancia com um cartaz dizendo "greve!". Chegava a polícia, dava um monte de empurrões, rasgava o cartaz e nos conduzia à delegacia; depois, deixavam-nos sair à noite. Essa coisa era um divertimento único, era uma grande paixão, muito apaixonante. Minha relação com o marxismo era especialmente uma relação com o fato de que, naquele momento, parecia refazer-se uma organização política. Eu vivia numa universidade que então dependia de duas seções: uma comunista, que se chamava seção Berutti, e uma socialista, que se chamava naturalmente Matteotti. Nesse lugar vicejava um grande proselitismo comunista ou socialista, e eu era secretário da seção Matteotti. Além das discussões relacionadas aos Quaderni rossi, havia também o fato de que no partido socialista de Turim, entre 1958 e 1962, havia uma espécie de onda bassiana. Creio que o "bassismo" seja uma entidade que existe só sob a forma de sua fundação, mas teve um breve fulgor que antecedeu os Quaderni rossi, ao qual aderiram muitas pessoas hoje espalhadas na 
esquerda em geral, mas que no Congresso de 1958 eram, de fato, bassiani, todos os que depois entraram nos Quaderni rossi. Minha relação com o marxismo foi muito pouco comunista: creio ser um tanto idiossincrático com o partido comunista, e isso é um fato talvez congênito. Tive uma tendência digamos laico-anarquista em vez de marxista, por isso acho que não tive muita simpatia pelos comunistas, especialmente na versão católica italiana. Pelo marxismo sim, mas pouquíssimo pelo trotskismo e pelo leninismo, e creio ter sido constantemente bem vacinado contra essas duas experiências. Não me vanglorio - no sentido que hoje em dia alguém usaria para se gabar -, mas não creio ter tido jamais uma forte inclinação pelo leninismo.

Um breve parêntese: em 1963 começava-se a falar de fusão entre o Partido Socialista Italiano (PSI) e o Partido Socialista Democrático Italiano (PSDI), então eu saí do partido socialista e a ele não mais retornei. Mas aqueles 5 anos contaram bastante na minha experiência política, mesmo na prática: em 1958, depois do término da experiência bassiana, todo o grupo, ou era egresso do PSI, ou tinha se tornando lombardiano. Lombardi dizia sempre: "é hora de sair do PSI, vamos mostrar àquele Nenni etc. etc.”. Saí pela terceira vez; Lombardi, ao contrário, não saiu. Constituímos uma corrente em Turim: fomos ao secretário da federação, que se chamava Muraro, e lhe dissemos: "constituímos uma corrente". Ele disse: "corrente é a mamãezinha", e desde então constituiu-se essa corrente do PSI de Turim que se chamava "corrente é a mamãezinha". Creio que contou muito em minha atividade como historiador a atividade prática de como se organiza uma seção, de como se discute com os companheiros etc. Sobre isso eu poderia contar muitas historietas, não agora...

Não creio ter tido uma paixão pela historiografia ético-política. Tive, sim, muita admiração por Franco Venturi, uma admiração cega: ele estava lá no Instituto de História de Turim, ou seja, era o grande historiador que tínhamos à mão; era, no entanto, uma relação conflituosa. Creio haver ainda um forte vínculo afetivo com Venturi, um vínculo recíproco, mas todas as vezes que nos vemos sobressaem as tensões. Declaro-me um estudante de Venturi, mas, se ele tivesse de fazer uma lista dos seus discípulos, certamente não teria em mente Giovanni Levi. Se houve alguma relação com a historiografia ético-política, eu a tive com Maturi. Maturi é um personagem também emotivamente envolvente. Era pequeno e gorducho, sorria o tempo todo e dizia coisas esmagadoras... era um personagem muito misterioso, muito irônico.

Nessa época eu achava que a única coisa séria era a história contemporânea; agora estou totalmente convencido do contrário. Talvez disso eu deva falar: creio ser importante compreender por que os historiadores tendem a ser 
mais hábeis quanto menos documentos tiverem em mãos, por isso penso haver uma disfunção dramática, do ponto de vista psicológico, para quem seja de história contemporânea. Recordo que uma vez Mannoni encontrou um pedaço de mármore na praça Matteotti, em Gênova; ele fez um buraco e depois o pendurou num muro, tendo ainda preparado um enorme cartaz no qual estava escrito tudo que daquele pedacinho ele conseguiu extrair, ou seja, uma proclamação completa de algum Cipião - não recordo mais quem. Penso que o tipo de ameaça que os documentos exercem sobre nós se torna quase insuportável quanto mais ampla for a documentação, de tal modo que uma pessoa não consegue manipulá-la; penso que isso pode ligar-se de algum modo ao argumento da micro-história.

Gostaria de alterar a ordem que tínhamos planejado para as nossas perguntas e colocar logo a questão, agora que você levantou, mas invertendo-a de cabeça para baixo. Por que a micro-história de fato não encontra um terreno fértil na história contemporânea?

Creio que, dado que a micro-história é essencialmente um problema de escala, o problema do tempo não seja relevante, ou seja, pode aplicar-se a qualquer coisa. Pensemos quais são os três melhores livros de história contemporânea que de súbito vêm à mente: a mim, surge sempre como o melhor livro de história contemporânea um livro não escrito por um historiador contemporâneo, ou seja, A grande transformação, de Polanyi (Polanyi, 2000). Acho que esse fato deve nos fazer pensar.

Eu gostaria de fazer uma pequena confissão de leitora. Ocupo-me de história contemporânea e sempre li seus artigos assim que saíam, mesmo sendo de história moderna, como se fossem artigos de história contemporânea. Evidentemente, esse esforço de restituição completa da realidade, que se encontra em seus escritos, é tal que anula a distância cronológica em que se situa o seu objeto. Isso eu digo porque permanece de pé a pergunta que fiz antes: não é um problema de escala, a escala é aplicável em todas as ocasiões, mas por que, em vez disso, quando se trata da história contemporânea, não é amplamente aplicada a não ser em extrema contiguidade com a antropologia ou, se preferir, com a história oral, para introduzir outro grande problema?

Penso que o problema não diz respeito à aplicabilidade da micro-história. É sobretudo verdade que o estímulo de colocar os "problemas de invenção", de ter a percepção de que estamos criando tanto o objeto historiográfico 
quanto o instrumento de leitura desse objeto historiográfico, é inversamente proporcional à proximidade no tempo. Creio que este dado seja, de fato, útil ao debate. É verdade, em outros termos, diria eu, que a história contemporânea, que certamente é mais estimulante que a história antiga, formula, todavia, os problemas dramáticos que frequentemente dão resultados menos brilhantes. Exige do historiador uma operação realizada com consciência menos explícita, com uma coragem menos explícita de saber que estamos criando o objeto que estamos estudando. $\mathrm{O}$ historiador contemporâneo trabalha mais sobre coisas, enquanto o historiador antigo é um criador mais explícito. Agora, sobre isso se pode discutir muito e retornar, mas não tem nada a ver com a micro-história. Além disso, não creio que a micro-história seja uma doutrina. Toda vez que nos pusemos a discutir o que é a micro-história, nenhum de nós foi capaz de dizê-lo, e nenhum de nós é, portanto, capaz de teorizar uma ortodoxia. A micro-história é uma prática e, em especial, uma aposta, uma discussão: é uma tentativa de trabalhar mudando a escala de leitura da realidade. A ideia de micro-história que têm aqueles que a praticam é de fato muito diversa, eu não me reconheceria na abordagem de muitos deles...

\section{Há no entanto parentesco, por assim dizer, entre vocês...}

Sim, há talvez parentesco, mas certamente não existe uma “ortodoxia”. Em poucos dias eu tenho de entregar um artigo sobre o que é a micro-história e estou desesperado! Tento sempre ir ao cinema, não pensar no assunto, porque é realmente muito difícil. Chegamos à conclusão de que se alguém deve escrever um artigo "o que é a micro-história", deve escrever um artigo sobre alguns conceitos-chave. Pode-se talvez dizer que para muitos a opção micro-histórica é uma espécie de declaração de desilusão, uma espécie de rebelião contra o fato de certas generalizações não responderem adequadamente aos problemas que colocávamos: tínhamos em mãos coisas que não contavam com nenhuma capacidade de previsão nem mesmo sobre o passado. Isto creio que seja importante no trabalho do historiador: os historiadores trabalham já sabendo como vai terminar - e esse é o nosso grande drama. Sabemos sempre quem é o assassino... Portanto, qualquer coisa dita por nós, qualquer nexo causal construído por nós, parece ficar de pé. Se dissermos "hoje é um belo dia, portanto em 8 de maio haverá eleições administrativas”, isso poderá parecer verdade: uma coisa depois da outra, parece conexão sensata.

Sabemos sempre como terminou e, consequentemente, somos levados a construir nexos causais muito pobres, mecânicos, automáticos, simples. 
A micro-história reagiu um pouco a esse problema. Disse "tentemos mudar a escala e complicar o quadro"; com cada um, em seguida, a complicar como quis, a usar a escala que quis. O contexto, por exemplo: é claro que, para Edoardo Grendi, contexto quer dizer o ambiente social em que um fenômeno ocorre. É evidente que, para Carlo Ginzburg, contexto quer dizer toda situação culturalmente análoga em que um fenômeno ocorre. Quando escrevi um livro sobre um exorcista, o contextualizei em um lugarejo. Ginzburg sustentava que uma contextualização legítima era a contextualização em todos os exorcistas, por exemplo. Isso é verdade, também o conceito de contexto é extraordinariamente discutível, fugaz. Mas não gostaria absolutamente de dizer que tudo isso não se pode fazer na história contemporânea. Penso - por exemplo - no problema do mundo relacional que discutimos, o problema das relações sociais devotadas à descrição da situação social em que um protagonista se move. Ninguém as avaliou até que Alberto Banti, um jovem especialista em história contemporânea, de maneira talvez discutível, tentou aplicar essas coisas, tentou desenhá-las concretamente.

Por que não o fizeram os medievalistas e especialmente os de história moderna? Talvez por preguiça, por desordem mental. Não é uma característica específica da historiografia moderna poder trabalhar com uma micro-história para examinar os problemas sociais.

Você diz que não pode trabalhar um modelo geral de micro-história - e você se explicou muito bem -, exceto que em seguida existem fortes e visíveis relações de parentela. Você pode apontar os pontos fortes identitários, fundantes, da sua proposta de micro-história?

Talvez devesse falar primeiro de parentela. Parentela é um termo extraordinariamente equivocado: vagas semelhanças. Na verdade, é um termo prenhe para micro-historiadores. Quando falamos de parentela imaginamos o fato de que trabalhamos com uma coisa de alguma maneira análoga. Ora, se me permite, adentro um discurso fatigante e confuso sobre o problema da analogia: serei brevíssimo, mas creio que seja muito importante.

Foucault num livro belíssimo, talvez o mais belo que tenha escrito, As palavras e as coisas (Foucault, 2007), disse essencialmente isto: no final do século XVII, o mundo vivia a elaborar sistemas de classificação analógicos, trabalhava sobre as semelhanças, sendo capaz de estabelecer conexões que a nós parecem em tudo impróprias (por exemplo entre o vermelho, o fogo, o sangue etc.). Toda a sociedade se lia culturalmente mediante um sistema analógico. Com uma mudança fundamental no curso do século XVII e depois do 
século XVIII, a sociedade tornou-se uma sociedade de igualdades, em que a analogia não era mais explicativa: a classificação tornou-se gênero e espécie muito mais baseada sobre a igualdade. Creio que os micro-historiadores trabalharam precisamente sobre essa questão, ou seja, rediscutiram o problema da analogia e da semelhança de família. Em que sentido?

Kant - mas se trata aqui da leitura que Rodney Needham faz de Kant em Reconnaissances (Needham, 2005) - disse que não devemos criar equívocos sobre o conceito de analogia: não devemos pensar que a analogia seja a semelhança parcial - "mais ou menos isso" (não é uma citação muito fiel!) entre duas coisas um pouco diversas, mas uma semelhança perfeita entre duas coisas completamente diferentes. Digamos que a analogia é segundo Kant a proporção “A está para B como C está para D”, em que o estar é que é igual, sendo A e C completamente diversos, como B e D são completamente diversos. Esse argumento (talvez eu use termos metafóricos, talvez não) me parece muito "sugestivo" a respeito de como se comportam os micro-historiadores: aquilo que temos colocado no centro do nosso trabalho me parece exatamente esse problema de situações inteiramente distintas mas que todavia nos sugerem mecanismos relacionais muito semelhantes, extraordinariamente semelhantes; insinuando a possibilidade de avizinhar coisas extraordinariamente distantes porque existe uma fortíssima congruência formal entre elas. Dando um exemplo muito trivial: penso que por estudar network na Piacenza do século XIX e na Florença do século XV podemos usar procedimentos semelhantes, exatamente porque retomamos, na pesquisa histórica, o problema da analogia.

Francamente, creio que este problema tenha figurado no centro do trabalho da micro-história: imaginar que, fazendo história social, devêssemos tentar encontrar mecanismos descritivos "polidos", formalizáveis.

Tenho muito orgulho do meu capítulo sobre a terra em A herança imaterial (Levi, 2000), um capítulo do qual todos dizem: "mas que absurdo..., demasiado simples...". Tenho muito orgulho porque me parece uma coisa "polida", que talvez esteja errada, mas que propõe uma medida extraordinariamente evidente e clara de um mecanismo econômico e social, e propõe refletir sobre isso. Todavia, este é um problema de comunicação muito importante para os micro-historiadores (e, creio, para todos os historiadores): a necessidade de comunicar os resultados, e não apenas realizar uma pesquisa, impõe limitações e é um problema que devemos perceber. 
Eu não sei se poderíamos considerar encerrado o problema central levantado há pouco, aquele da proporção de escala em relação à adequação da micro-história na história contemporânea. Parece-me que na história contemporânea a coisa se complica porque os problemas de escala geral frequentemente assumem um significado muito alto e a escavação em uma realidade circunscrita e delimitada não pode em seguida superar uma espécie de nível de senso comum, de conhecimento geral que possuímos enquanto homens contemporâneos, enquanto "registradores" de fenômenos que estão diante dos nossos olhos. Para tornar compreensível o problema, refiro-me a uma experiência pessoal de pesquisa. Estudando a agricultura do Sul da Itália, não consegui entender por que, no curso dos séculos XVIII e XIX, os olivicultores calabreses ou da Puglia produziam o chamado óleo "rançoso". De acordo com as fontes locais tudo isso se devia à preguiça, à ignorância, a certa atitude "rentista" dos grandes proprietários, os quais não se importavam em melhorar essa produção porque as relações sociais, os contratos agrários dominantes nos campos calabreses, permitiam uma fonte de renda segura que não incentivava a inovação. Tentei longamente não problematizar esse tipo de resposta, investigando por exemplo que relação havia entre a capacidade tecnológica das usinas locais e essa incapacidade de produzir óleo fino, de mesa.

Encontrei a resposta saindo do âmbito local, saindo do âmbito calabrês, quando descobri que o óleo "fedorento" produzido na planície de Gioia Tauro era procurado e adquirido na Inglaterra pelas fábricas de panos de lã (porque o óleo - embora fedorento - servia para suavizar a lã), ou pelas fábricas de sabão de Marselha. Esse deslocamento de escala foi para mim decisivo para entender as atitudes do microcosmo na Calábria e na Puglia. Parece-me que iniciativas desse gênero na história contemporânea têm um poder perturbador maior do que seja possível no campo da história mais antiga.

Não penso assim. Definamos a micro-história: a micro-história - a meu ver - não tem nada a ver com história local, e gostaria de dar um passo atrás. Para mim o interesse pela micro-história nasceu de uma experiência talvez banal e que talvez não devesse mesmo contar. Vocês sabem que em 1968 houve uma série de movimentos na Itália (movimento estudantil, o Outono Quente etc.). Nos anos subsequentes, militei em um grupo atuante em uma zona do Piemonte, o baixo vale Susa. Nesse grupo nós fazíamos um levantamento sobre a folha salarial de algumas fábricas e, em particular, tínhamos em mira o salário por peça. Um belo dia aprontamos um panfleto onde explicávamos como funcionava o pagamento em uma fábrica, a Marchisio. Os operários da fábrica 
saíram e, após lerem os folhetos, disseram: "nós estamos espantados; não ligamos nada para a empreita, nós nunca entendemos como funciona, estamos muito admirados que vocês tenham perdido o seu tempo com esse negócio todo, mas saibam de todo modo que para nós o trabalho de fábrica é uma coisa muito desagradável, não nos divertimos absolutamente. Para nós, a libertação da fábrica é largar o serviço e fazer outra coisa com o nosso tempo livre". Essa experiência pode multiplicar-se por cem. Todos nós a tivemos e é, aliás, uma experiência da história contemporânea: a experiência de certa rigidez de interpretação que diante da realidade entra em crise e, portanto, se defronta com problemas novos. Penso que os problemas da micro-história são essencialmente estes: problemas generalíssimos, mas, diminuindo a escala, percebemos certas sugestões, sinais - para usar uma terminologia cara a Ginzburg - de alguma discrepância que, em nível geral, não conseguimos explicar, nem mesmo perceber. Estou convencido de que os micro-historiadores se debruçam, reduzindo a escala, sobre problemas muito gerais. Por exemplo, tive talvez a petulância de realizar um seminário nos Estados Unidos intitulado: "Índia, Inglaterra, França, Estados Unidos e um vilarejo no Piemonte” sobre o problema do mercado da terra. O escopo era paradoxal, era como dizer: se nós continuamos a falar do mercado da terra falando dele no atacado não entendemos nada, não entendemos por que os preços são tão dispersos e irregulares; tentemos ver o problema de um mercado local, para ver o real funcionamento, para formular diretamente a pergunta, para observar o papel das relações sociais na formação dos preços, em cada transação; então naturalmente devemos voltar a trabalhar sobre os problemas mais gerais. Os micro-historiadores são frequentemente acusados de agirem como porta-bandeiras de uma ortodoxia e de desvalorizar outras abordagens, mas a questão é outra. Encontramo-nos às vezes (para dizer a verdade, muito frequentemente) diante de problemas que não explicamos: nos esforçamos para ver, mudando a escala, se não nos defrontamos com outras realidades, com problemas diversos. Na verdade, pretendemos exatamente a generalização; prefiro acreditar haver sempre sugerido destinar menos importância à comunidade específica, ao "lugar" estudado, sustentando que o problema histórico geral fosse "o" problema, e daí que o seu ponto de aplicação seja quase acidental. Ecco! É por isso que a história do óleo rançoso não me parece contradizer este argumento: decerto, se não havia explicação no olhar local, não há nada contra a ir procurá-la na Inglaterra. Ocupar-se do óleo rançoso é uma operação micro-histórica. 
É micro, mas é também macro, porque sugere uma relação entre a grande história e o argumento particular: é uma relação que deve existir, caso contrário não tem valor nem uma coisa nem outra. Quero, porém, fazer outra pergunta: você negou que haja algum tipo de "teoria dos micro-historiadores”, mas, de acordo com o que pensa, a micro-história é a estrada mais corajosa, aquela mais justa, ou uma das tantas que podemos percorrer?

Talvez nenhuma dessas três coisas. Depende realmente dos problemas. Nós nos defrontamos, nos últimos meses, com a queda do muro de Berlim, e nos indagamos por que poucos de nós a haviam previsto ou tiveram condições de prevê-la (mesmo hoje não somos capazes de prever o que ocorrerá como consequência da queda do muro). Por enquanto possuímos as explicações macro do que está acontecendo, que tipo de agregações políticas estão se desenvolvendo, e debatemos estes problemas: são necessárias explicações micro e macro para entender o que se passa na Romênia, o que ocorrerá e o que está ocorrendo na Alemanha e assim por diante.

Creio que o problema da micro-história esteja ligado ao fato de que algumas explicações gerais não davam retorno; era necessário reorganizar a descrição do mundo social para deixá-la mais concreta. A conceituação que possuíamos e possuímos à disposição mostrou a sua decepcionante fraqueza.

Por isso é uma escolha de "lentes": em certo ponto, com certas lentes não se vê; então trocamos as "lentes"...

Vou dar um exemplo: nesta manhã eu discuti com um jovem historiador que faz uma pesquisa sobre Masaniello e se perguntava por que tudo aquilo que foi escrito sobre Masaniello era contraditório e não convencia. Acreditava ser necessário encontrar outros documentos que subitamente modificassem o que é conhecido. Mas a questão não é ir procurar outras coisas, mas alterar a escala: mudemos a escala, vejamos com outra escala as mesmas coisas, pois agora temos as redes, pessoas afirmando uma o oposto da outra - e podemos dizer apenas se estamos pelo sim ou pelo não (um pouco como no debate sobre o Partido Comunista Italiano). Esse problema envolve uma infinidade de coisas que ocorreram na história do mundo, inclusive muito recentemente, dentre outras tantas. Todos nós fomos de qualquer modo influenciados pelo marxismo, por exemplo, e fico espantado quando vejo que de repente ninguém é mais marxista; é uma coisa terrível, arrepiante. No curso de uma semana desapareceu tudo; isso é verdadeiramente muito pesado, atroz, mas é um sinal de que é necessário um pouco de micro-história. Talvez devamos pegar a lupa e ver 
como uma ideologia dominante pode desintegrar-se desse modo, sem legar uma base de consenso, que, diferentemente, até mesmo o franquismo deixou.

Entre os historiadores que conheci, nenhum tinha uma relação com as ciências sociais como a de você e do grupo turinês que se formou em seu entorno. As questões que você se colocava eram ligadas a uma discussão interna às ciências sociais e, portanto, não eram questões só tipicamente históricas. Isto também me parece importante para definir a micro-história: a questão que se coloca é aquela do mundo, é o problema da transformação social.

Devo dizer uma coisa só aparentemente metafórica, mas concreta: acredito que os historiadores não só não devem ter uma subalternidade em relação às ciências sociais, mas devem, também, criar ciências sociais. Discutindo o manuscrito de Alberto Banti (posteriormente publicado com o título Terra e denaro. Una borghesia padana dell'Ottocento, Banti, 1989), eu tinha certa obsessão: havia uma aparente e retórica estranheza entre as ciências sociais e a história em seu livro. Havia esta frase: "nós não sabemos isto e aquilo, mas Olson vem em nosso socorro". O problema não é o do socorro providenciado pelas ciências sociais à história, mas sim o da contribuição da história e das ciências sociais à criação de novos conceitos, de novos instrumentos de interpretação e descrição da realidade. Penso que, na Itália, os historiadores especializaram muito as suas leituras, no sentido de ler apenas historiadores, e frequentemente historiadores italianos. Esse é o resultado clássico de uma ciência muito corporativa. Realizamos um trabalho muito bom de discussão entre nós, mas acredito que, objetivamente, o problema em relação à formação dos micro-historiadores seja a abertura a outras disciplinas e às contribuições provenientes de outros países. Nisso o verdadeiro mestre é Edoardo Grendi que, sendo mais inglês que genovês, e tendo estudado muitos anos na London School of Economics, sugeriu a muitos de nós uma relação estreita com a antropologia social inglesa. Não creio, naturalmente, que isso seja exclusivo dos micro-historiadores: por exemplo, é Arnaldo Momigliano quem primeiro resenha Marshall Sahlins na Itália.

Gostaria de retomar algumas questões sob a forma do percurso biográfico (me parece que esta contraposição apodítica de modelos seja de difícil recepção). Estou muito impressionado por algumas das coisas que você disse anteriormente, relativas ao modo como nasceu a micro-história na Itália. A grande metáfora da relação entre história e ciências sociais encerra na realidade uma questão muito mais específica e definida, que foi agora precisa- 
mente evocada, isto é, a relação entre história e antropologia. A vocês, micro-historiadores, interessa muito pouco da economia e da sociologia concebidas no sentido clássico, salvo para utilizar tudo aquilo que é útil dentro dos percursos da pesquisa. O nó em que vocês investiram, do ponto de vista de uma epistemologia das ciências sociais, foi a relação entre história e antropologia, isto é, a questão - que para mim é consequentemente a central - da mudança da atenção do objeto para os procedimentos. Esse modo de olhar os critérios das relações como o coração e o fulcro da reconstrução historiográfica é uma questão que agora me parece clara, no sentido de que é clara uma prática concreta que mostrou quais frutos pode trazer essa mudança de acento e de ótica. Mas dois problemas permanecem: de um lado, o que ocorre com os objetos nesse deslizamento do olhar, do material para o procedimento, isto é, o que ocorre com o senhor que vendia a terra ou um barril de óleo rançoso; e de outro lado - e este é o ponto que talvez menos me convence -, o motivo pelo qual essa redução de escala, que indubitavelmente é muito útil para indagar-se do ponto de vista de um critério "relacional", deve ser operacionalizada em termos tão rigidamente exclusivistas como vocês têm feito. Parece-me que uma verdadeira e precisa averiguação e uma extensão da validade desse critério não só pode mas deve ser buscada em outros e mais complexos níveis de escala.

Se a relação funciona, e funciona nessa escala tão pequena, então deve ser demonstrável o funcionamento também em níveis de escala mais complexos. Cito essa questão porque faz parte de um ponto de encontro biográfico nosso; quando alguém se pôs a trabalhar com história regional, você disse que esse era um caminho absolutamente impraticável (naturalmente ninguém, ou pelo menos não todos, pensávamos numa história das regiões como uma dimensão absolutamente ordenada ou institucional)...

O que me interessava entender é o porquê dessa insistente importância do termo micro. Ainda que eu reconheça a funcionalidade e a força de uma instância redutiva para investigar o modelo relacional, não compreendo por que tudo isso não possa ter aplicação também mais larga, mais extensiva; na verdade, parece-me autolimitante impedi-lo; parece-me uma limitação, uma armadura que ideologicamente vestimos e que, então, nos impede de raciocinar de maneira um pouco mais flexível.

Há na sequência outro aspecto que vale a pena ligar ao seu artigo "Regioni e cultura delle classi popolari” (Quaderni storici, n.14), em que você coloca a questão da "região débil” e do "município forte", por assim dizer. Relendo-o nestes dias, pensei: suponhamos que você tenha razão; é verdade, no entanto, 
que se podem ver então emergir áreas amplas em que há pontos de chegada comum. Tenho em mente o exemplo do chamado "continente mezzadrile". Internamente há fortes diferenças (uma região-Estado como a Toscana, uma região débil como a Umbria), mas, em certo ponto, emerge no entanto um horizonte comum, por exemplo no sentido político e cultural, e esse horizonte comum evidentemente tem raízes na cultura camponesa. Existe aí o forte desempenho de fatores homogeneizantes: do interior do município não se vê, mas, de todo modo, em algum ponto essa área é novamente percebida, demonstra que existe. Que relação há entre o município forte e essa área mais ampla?

Seriam três as respostas.

A primeira é muito remota: não é verdade, não se trata apenas da relação entre história e antropologia. Muitíssimos dos bons resultados verificados na micro-história são relativos à relação com a economia. E creio que até o debate em curso entre os economistas, com a crise da economia neoclássica, ofereça sugestões importantíssimas.

Quanto à mudança de atenção do objeto para os procedimentos, eu não diria: "nós modestamente fazemos o nosso trabalho", no modo narcisista e petulante típico dos micro-historiadores; mas penso que seja realmente assim, isto é, penso que os micro-historiadores têm todos um problema análogo na hora de afinar instrumentos, construir instrumentos, discutir os instrumentos. Estou de acordo em que a história sirva para dar grandes interpretações, para nos reexplicar o mundo, mas o real momento de estagnação em que estávamos deriva do fato de os nossos instrumentos estarem um pouco enferrujados: parecia-nos então que eram usados como carimbos, e que a coisa não funcionava mais. O trabalho dos micro-historiadores tem se esforçado em reconstruir a possibilidade de uma interpretação com elaborações em torno a uma contextualização e aos procedimentos. Apesar, talvez, de sua petulância, os micro-historiadores têm o mérito de colocar em discussão, submetendo à prova a autoridade do historiador. Quer dizer, colocam questões sobre por que e como trabalham, o que estão fazendo, dentro de quais limites é verdade o que estão dizendo. Por uma tendência que desenvolvi nestes anos, os livros de história em que se dão vereditos definitivos me deixam bastante perplexo; é necessário reabrir na história o espaço para as incertezas e indecisões. Certamente é necessário chegar a generalizações, mas é oportuno um esforço de rediscussão dos nossos instrumentos, evitando chegar a afirmações arbitrárias.

Sobre o problema região-município: a referência concerne a uma discussão ocorrida há muito tempo, relativa ao projeto de história regional da editora Einaudi. Estou de acordo em relação ao fato de existirem áreas comuns. No 
entanto, tenho para mim que é muito importante sublinhar a prevalência do localismo sobre a agregação, e que as regiões são criações artificiais, administrativas, cuja história é em grande parte impossível de fazer: não devemos ideologicamente esquecer a artificialidade de sua condensação atual.

Talvez fosse oportuno questionar também as exigências historiográficas a partir das quais amadureceu a escolha micro-histórica de historiadores de formação muito diversa (também Carlo Poni é um micro-historiador, mas absolutamente distante de Carlo Ginzburg).

Em sua opinião, de quais questões iniciais partiram esses historiadores com formação intelectual diversa, e quais são as perspectivas atuais? E que papel teve nesse debate uma revista como Quaderni storici? Outra: você fez pouca referência à categoria da indecisão, eu gostaria de saber o que é a incerteza. É o estatuto epistemológico da micro-história ou a incerteza do fato de que nós, não possuindo o objeto, não podendo colhê-lo de qualquer maneira, encontramo-nos diante de relações que são sempre ambíguas e, portanto, não podemos possuir um estatuto de certeza?

Outra: a propósito do estatuto epistemológico e de incerteza, em termos de método você faz referência a figuras retóricas como a analogia, a metáfora etc., que em seguida fazem parte do método de argumentação, que, em seguida, por sua vez, refere-se à verossimilhança. Muito frequentemente, o ponto de chegada do micro-historiador é contar algo verossímil que enquanto tal possui legitimidade de ciência. Você não crê que, ao invés da categoria de verossimilhança - certamente uma pesquisa histórica não pode encontrar a verdade, porque não há -, devêssemos fazer referência - como faz a ciência moderna, que também deixou a lógica clássica da relação causa-efeito - à categoria de possibilidade? O físico quântico, por exemplo, não diz que é verossímil a sua teoria sobre a energia, mas que é altamente provável com base em experimentos repetitivos, isto é, verificáveis.

Há também uma estranha semelhança com certas práticas judiciárias: o processo indiciário faz danos terríveis sobre o plano jurídico e talvez sobre aquele historiográfico...

E há outra questão: a relação entre o "normal” e o "excepcional”. Qual é a sua opinião, e em que modo esses termos foram discutidos em uma revista como Quaderni storici? Finalmente, outra questão mais geral: a todos nós ocorreu questionar o que significa realmente o fazer do historiador, que im- 


\section{portância tem questionar sobre o que ocorreu no passado. Há alguma refle- xão particular nesse tema?}

O elo entre Quaderni storici e as questões colocadas é um problema muito difícil porque, até hoje, esse periódico não é a revista dos micro-historiadores. Ali escrevem historiadores que não se consideram como tais, tendo sido fundada por macro-historiadores que trabalham ainda a pleno vapor. Por isso é muito perigoso identificá-la assim. Quaderni storici tem sido uma revista muito experimental, creio que a mais experimental da Itália, e nesse sentido tem hospedado (e também dado) um forte peso ao trabalho dos micro-historiadores, mas, ainda mais, e não por acaso, ao debate teórico sobre micro-história. Há textos que são considerados pedras angulares. Eu reli "Il nome e il come" [“O nome e como"]: me pareceu de uma velhice verdadeiramente impressionante, era uma coisa de ocasião, embora tenha tido muita consequência nas citações e na imagem da micro-história.

A consequência fundamental foi a de difundir no mundo a frase deliciosa e sem sentido de Edoardo Grendi: "o excepcional normal”. Não creio que se possa dizer que a micro-história nasceu dentro dos Quaderni storici: nasceu discutindo com Carlo Ginzburg - talvez mesmo antes que Carlo entrasse nos Quaderni storici - e com Giulio Einaudi. Veio à luz na vontade de uma coleção (Microstoria), em que pensávamos tentar reunir, ao lado da pesquisa italiana, alguns textos que inspiraram uma renovação da historiografia italiana. De certo modo, estávamos em polêmica com uma identificação, muitas vezes insinuada, a meu ver injustamente, entre renovação da historiografia francesa em torno dos Annales e micro-história. Nós, se tanto, nos esforçamos para preencher a coleção com americanos e ingleses, nos indagamos sobre algum autor alemão, mas não foi por acaso que, à parte Jean Claude Schmitt, não houve muitas presenças francesas. Propúnhamos que a historiografia italiana, devagarinho, tentasse, quer se renovar, quer superar uma dependência real, colonial, digamos, que havia de fato, das invenções dos outros.

A coleção veio a lume mais tarde, mas aquela discussão em torno da ideia de fazer uma coleção e de recolher os livros fundantes desenvolveu-se por volta de 1974, 1975 e 1976. A coleção teve muitas e dolorosas crises ligadas a si própria e à editora, do mesmo modo como Quaderni storici teve crises desastrosas, até se tornar agora uma revista "estabelecida" qualquer. Provavelmente supérflua.

Quaderni storici era uma conversa. Penso que muitas das exigências eram ligadas aos acontecimentos políticos, além dos culturais, isto é, eram demandas associadas ao fato de que nos encontrávamos sempre diante de coisas de difícil 
compreensão (continuo a pensar que sou um micro-historiador porque continuo a não entender por que ganham sempre os democrata-cristãos: gostaria de encontrar a grande e a pequena escala que explicassem como é que nos damos mal, sempre).

O problema da incerteza. É um problema fundamental para os historiadores, e por motivo banal. Nós, por razões ligadas aos nossos procedimentos de historiadores e ao tipo de documentação que possuímos, descrevemos os nossos personagens como personagens que decidem, isto é, estamos sempre a operar sob suas ações e decisões. Aquilo que tem sido enormemente discutido na literatura do século XX é exatamente o contrário: a indecisão, a imprecisão, a indefinição da identidade. No curso do século XX abriu-se uma enorme lacuna entre história e literatura, mais do que nunca. Os historiadores sempre tiveram de escrever biografias dos seus personagens, e até de personagens massacrados, trajetórias de homens que, no entanto, decidiam e agiam. Isto é, para mim, sempre um motivo para interrogação: por que ler as histórias de nenhum interesse da senhora sentada em seu banquinho ou do homem sem qualidade, que apreciamos muito; mas por que nunca permitiremos a um historiador ocupar-se de bobagens desse gênero? Como é que as perguntas e os personagens são tão diversos assim? Parece-me que um dos nós seja precisamente o da incerteza, pois a incerteza não é um elemento que entrou na história como a decisão; e também a dificuldade de tomar decisões entrou apenas lentamente na história. Pense-se, por exemplo, em Leibenstein: ele tentou introduzir a não decisão em todas as teorias de decision making, buscando examinar se não havia uma área em que todos os fatores impediam a realização das escolhas, e quais consequências essa área produziria na teoria econômica. $\mathrm{O}$ fato de Buridano ser o filósofo do nosso século me parece muito importante para os historiadores. Estou escrevendo agora um livro sobre a incerteza. É um livro experimental. Tomemos 10.248 artesãos, digamos a eles que tomarão decisões quando forem adultos: sobre o seu mercado, sobre seus filhos etc. (estamos ao fim do século XVIII). Esses pobrezinhos decidem, incautamente, segundo modos e mecanismos diversos. Em seguida, estouraremos em suas orelhas a Revolução Francesa. Chegam os franceses e todo esse mundo que dispunha seus arranjos econômicos é sacudido pelo fato de, por exemplo, os peruqueiros (aqueles que fazem perucas) serem colocados para fora do mercado. O que ocorre a um formigueiro quando o desfaço com o pé? Tenho buscado inventariar e discutir os procedimentos pelos quais um historiador pode analisar mecanismos de ruptura, recomposição e paralisia das decisões. Outro aspecto da indecisão talvez seja a alegria de participar da vida política mesmo quando se está enganado. Quando 
escrevi o livro sobre Giovan Battista Chiesa, pensava sempre em Vittorio Foa: tem perdido sempre, mas está sempre contentíssimo. Creio ser este um belo problema histórico: consideramos que as pessoas se empenham politicamente pelos objetivos que devem obter. Ao contrário, quase todos nós nos sentimos satisfeitos, na vida, mesmo sem obter nada, na verdade.

Queria ainda dizer algo sobre o problema da irregularidade e da excepcionalidade, e depois, da probabilidade e da verossimilhança. Houve uma famosa discussão entre Momigliano e Hayden White. Este último sustenta que a atividade do historiador é pura retórica, e Momigliano diz que "nós trabalhamos sobre a verdade, isto é, procuramos a verdade". Fico ao lado de Momigliano. Mas creio que estava em parte errado, que havia subestimado o significado também retórico da pesquisa histórica. Estou convencido de que trabalhamos procurando a verdade, me repugna uma história relativista. Uma das tarefas trazidas pela micro-história é a de melhorar a nossa capacidade de descrever a realidade. Todavia, devemos ter em conta que há também um forte papel da retórica, há o problema de comunicar os nossos resultados e ainda de usar, no bom sentido, os truques. Por exemplo, um truque clássico e um erro das técnicas argumentativas dos micro-historiadores é dizer "todos os cardeais possuem uma família muito importante, por exemplo, o cardeal da família fulano de tal...", apresentando um caso para assegurar que todos os outros são uniformes. Seria muito mais convincente se se descrevessem mais cardeais, ou melhor, todos os cardeais. Esse problema da técnica retórica liga-se àquele da busca da verdade, e estamos de acordo que, quando falamos de verdade, não falamos da verdade, mas de algo que, de certa maneira, parece efetivo, demonstrado e a ser debatido. Na micro-história e também na historiografia recente, uma novidade positiva é a de também sugerir os limites da verdade na qual se crê: não se diz mais “ocorreu assim”, mas "desses elementos, tiramos esta conclusão". Isso é extraordinariamente correto e é, de novo, um problema ligado à relação entre história e antropologia.

No que concerne à última questão, e em relação à questão do que é mais importante, os $95 \%$ da realidade ou os $5 \%$ restantes. Em geral há duas técnicas descritivas da realidade que se contrapõem: uma é aquela de estudar o fenômeno mais difuso; a outra busca explicar o sistema tendo em conta, simultaneamente, os fenômenos mais difusos e os menos difusos. Por exemplo: família nuclear e outros tipos de família. Alguém argumentou que o tema relevante sobre o qual se interrogar é aquele da família prevalecente, outros nos propuseram, a meu ver mais adequadamente, explicar por que, mesmo sendo $5 \%$, ao lado das outras havia também $5 \%$ de famílias de tipo diverso. É uma diferença 
de leitura a respeito da atitude do cientista: um é funcionalista, e tende a considerar marginal, desviante, qualquer fenômeno de descarte, tanto mais se há uma forte concentração modal central; outros, ao contrário, alegam que o conjunto de todos os fenômenos deve ser explicado dentro de um sistema do qual nada é colocado para fora. A primeira atitude, não obstante muito difundida, pode ter também consequências penosas: é possível, por exemplo, partir de uma concepção de normalidade e considerar desviantes os $5 \%$ diferentes. Outros visam explicar o sistema por inteiro, considerando que qualquer posição dentro desse sistema seja explicada pela presença de outras coisas.

Algumas perguntas muito esquemáticas. Gostaria de saber qual é, em usa opinião, a base do sucesso que teve L'eredità immateriale (A herança imaterial, Levi, 2000), ligando essa pergunta a outra, mais geral, sobre o público dos livros de micro-história. Não é possível que o sucesso dos livros de micro-história dependa do fato de serem obras de história que se assemelham muito a produtos artísticos, com uma característica que as torna atraentes no mercado internacional?

Outro ponto, de novo sobre as questões micro-históricas e a necessidade, sobre a qual estamos de acordo, de haver uma boa preparação cultural de base para colocar depois certas questões no micro. Partindo dessa premissa, o que pensa você como mestre universitário: há sentido em destinar a um estudante, que talvez não tenha certa capacidade, a tese da micro-história?

Na verdade, me parece que $A$ herança imaterial (Levi, 2000) não tenha tido um grandíssimo sucesso: decerto, houve curiosidade intelectual, até para compreender o tipo de aproximação que eu propunha.

Indo mais além: há certos livros de micro-história que se colocaram o problema da narrativa, mas estão em jogo muitos outros fatores. Por exemplo o livro de Ginzburg, Indagini su Piero (Ginzburg, 1981), foi traduzido em muitíssimas línguas, assim como o livro de Pietro Redondi sobre Galileu (Redondi, 1991), e ao mesmo tempo o livro de Ramella, Terra e telai (Ramella, 1998), que, embora belo e também bem escrito, não foi traduzido em nenhuma língua. Creio que também seja um problema de diplomacia internacional, no sentido do mercado internacional das editoras, das universidades. Sem negligenciar outros elementos, mais particulares. Nem sempre a micro-história discutimos há pouco - foi aceita por sua capacidade de propor um método e conceitos generalizáveis. Frequentemente é imaginada como uma história local, um pouco como ocorreu com Franco Ramella. Por exemplo, uma vez 
Ramella foi até Nova York estudar os biellesi e encontrou na lista telefônica "cooperativa biellesi de New York". Foi lá, e entrou numa velha fábrica abandonada onde havia velhíssimos biellesi que jogavam cartas. Então ele se aproxima de uma mesa, senta-se e pergunta a um velhinho que estava jogando cartas: "o senhor é de Biella? Eu sou de Biella e estou aqui para estudar a emigração biellese etc.”. O velho diz "mas que prazer", fazem festa, depois o velhinho se empertiga um pouco e lhe diz: "Mas é de Biella, Biella?", "Sim, sim, exatamente da cidade de Biella". Então o velho lhe diz: " $m i$ su 'd Cumanduna" e não lhe dá mais atenção. Noutras ocasiões, finalmente se disse: como Piero della Francesca (Ginzburg, 1981) ou Galileu (Redondi, 1991) podem ser micro-história? O acento sobre a escala de observação mudou para uma definição banal da dimensão do objeto. Este, se é pequeno, não é entretanto pequeno o bastante para o pessoal de Comandona [a menos de $15 \mathrm{~km}$ de Biella].

A segunda questão: o problema do ensino. No primeiro período em que se discutiu a micro-história, a polêmica "mas como explicar Maomé com a micro-história?” está mesmo estampada nos jornais. Naturalmente, esse não é o problema. Percebi no ensino universitário que, nos últimos anos, digamos depois de 1975, os estudantes têm assumido uma atitude ansiosa para aprender e também muito subalterna ("aquele ali que está na cátedra diz a verdade"). Esta é uma situação muito dramática do ponto de vista didático, porque a autoridade do docente é fortíssima e a ponte com os estudantes, nula. Durante anos (penso que até agora), certos procedimentos micro-históricos significaram muito, exatamente na criação de uma ponte entre um problema extraordinariamente distante dos alunos, como por exemplo Maomé, e os próprios alunos: a criação de uma ponte sobre mecanismos de relevância. Por exemplo, a mim impressiona como os alunos permanecem interessados estudando a história da família: partindo de suas famílias como exemplo e chegando aos problemas de generalizações.

Claro, é muito difícil fazer uma ponte entre fatos históricos e micro-história se esquecemos que o verdadeiro problema não é de conteúdo específico mas de procedimento, isto é, demonstrar como pequenos fatos aparentemente insignificantes estão cheios de significados históricos complexos. Nesse sentido, a micro-história tem tido enorme papel didático; o erro é dizer "ensino só coisa ocorrida em Tivoli".

Há algo que não me convence no que tange às oscilações, que você coloca, entre a premissa do método e a atribuição de objetivos à micro-história: primeiro discutíamos os conceitos base da micro-história e você dizia que há 
alguns conceitos-chave, eu creio que seja o conceito dos conceitos, isto é, o conceito fundador da micro-história. O problema é: por que alguém deve sentir a necessidade de reduzir a escala? Você primeiro deu uma resposta, a propósito de Santena [vilarejo do Piemonte]: sobre Santena não importa nada, isto é, o que interessa é tentar ver como funciona o mercado da terra, porque o objetivo é destruir as proposições teóricas que estão na base da análise corrente. Em outros termos: a unidade das análises é reduzida para dar uma contribuição às ciências sociais. Mas há também outra resposta: reduzimos a escala porque somos verdadeiros historiadores e queremos dar uma resposta aos problemas de caráter histórico. Porém, nesse ponto, o problema se coloca nestes termos: se a redução da unidade de análise tem como objetivo relançar a proposta teórica, parece-me que tudo funciona, no sentido que, se você pode refutar, ainda que sobre um pequeníssimo fragmento, uma teoria geral, esta deve reconhecer que não pode ser extensiva a todo o problema; todavia, não é claro como se pode passar do particular analítico à solução macro-histórica.

Estou por um lado de acordo com você e, por outro, em completo desacordo. Para mim, o que a micro-história fez até agora não é certamente a possibilidade de descrever melhor Felizzano ou Santena, mas sugerir quais perguntas propor. Por exemplo, se alguém afirmar que, nesses mesmos anos, existe em Módena um mercado absolutamente perfeito, em vez de embebido em relações sociais, para mim está tudo bem. O que tem me deixado perplexo lendo os livros que se ocupam do mercado da terra - uma bibliografia relacionada essencialmente à Inglaterra, aos Estados Unidos, à França e à Índia - é que nenhum examina o nível dos preços, isto é, que todos disseram: há um mercado enquanto existe uma transação expressa em moeda. $\mathrm{Na}$ verdade, o problema era a extrema dispersão dos dados, que só se podia perceber reduzindo a escala de observação e, assim, evitando médias e agregações. A minha proposta construtiva não é "cem Santena", mas "cem perguntas similares àquelas feitas sobre Santena”, isto é, sobre como se formou e modificou certo preço. Não me parece contraditório. Admito que a intolerância recíproca criou zonas francas que os micro-historiadores não podem cruzar.

No fundo, parece-me que você confirma a observação que lhe foi feita, isto é, que a produtividade deve ser buscada do lado das ferramentas conceituais.

Sim, disso estou firmemente convencido, e creio que a coisa mais divertida é inventar os problemas e as ferramentas que outros possam, na sequência, aplicar. 


\section{REFERÊNCIAS}

BANTI, Alberto Mario. Terra e denaro: uma borghesia padana dell'Ottocento. Venezia: Marsilio, 1989.

DOLCI, Danilo. Spreco: documenti e inchieste su alcuni aspetti dello spreco nella Sicilia occidentale. Torino: Einaudi, 1962.

FOUCAULT, Michael. As palavras e as coisas: uma arqueologia das ciências humanas. São Paulo: Martins Fontes, 2007.

GINZBURG, Carlo. Indagini su Piero: il battesimo, il ciclo di Arezzo, la flagellazione di Urbino. Torino: Einaudi, 1981.

LEVI, Giovanni. Centro e periferia di uno Stato assoluto: tre saggi su Piemonte e Liguria in età moderna. Torino: Rosenberg \& Sellier, 1985.

. L'eredità immateriale: carriera di un esorcista nel Piemonte del Seicento. Torino: Einaudi, 1985a.

. A herança imaterial: trajetória de um exorcista no Piemonte do século XVII. Rio de Janeiro: Civilização Brasileira, 2000.

NEEDHAM, Rodney. Reconnaissances. Ann Arbor: Books on Demand, 2005.

POLANYI, Karl. A grande transformação: as origens da nossa época. Rio de Janeiro: Campus, 2000.

RAMELLA, Franco. Terra e telai: sistemi di parentela e manifattura nel Biellese dell'Ottocento. Biella: Libr. Vittorio Giovannacci, 1998.

REDONDI, Pietro. Galileu herético. São Paulo: Companhia das Letras, 1991.

\section{NOTAS}

${ }^{1}$ Original disponível em: http://www.rivistameridiana.it/files/Intervista-a-Giovanni-Levi. pdf. Tradução: Antonio Luigi Negro e Jonas Brito. Os tradutores agradecem a Henrique Espada Lima Filho, Verónica Secreto e Laura de Oliveira. A publicação desta tradução foi autorizada tanto por Giovanni Levi quanto por Rocco Sciarrone, codiretor de Meridiana, aos quais também agradecemos.

${ }^{2}$ Azionismo refere-se ao Partito d'Azione, criado na Itália em 1942 da confluência entre liberal-socialistas, republicanos e a organização clandestina e antifascista Giustizia e libertà. Propunha-se a combater o fascismo e superar a antítese entre liberalismo e socialismo. A partir de 1944, graças ao prestígio adquirido na resistência antifascista, tornou-se uma das forças políticas mais dinâmicas do país. Em 1947 foi dissolvido por cisões internas, principalmente entre a ala socialista, a liberal-socialista e a liberal-democrática e republicana. Os azionistas remanescentes migraram para os partidos socialista, republicano, socialista democrático e comunista. Conferir o verbete Partito d'Azione na Enciclopedia Treccani. Disponível em: http://www.treccani.it/; Acesso em: 21 nov. 2015. (N.T.)

Entrevista recebida em 21 de março de 2017. Aprovada em 27 de março de 2017. 
Erratum: O pequeno, o grande e o pequeno: Entrevista com Giovanni Levi

No artigo "O pequeno, o grande e o pequeno: Entrevista com Giovanni Levi”, DOI: 10.1590/1806-93472017v37n74-07, publicado no periódico Revista Brasileira de História, vol. 37, n. 74, na p. 157, onde se lia:

Tradução: Antonio Luigi Negro e Jonas Brito ${ }^{1}$

Entrevista realizada em Roma, em 16 de fevereiro de 1990. Com pauta preparada por Guido Crainz, Gino Massullo e Giacomina Nenci, foi publicada no número 10 de Meridiana, em 1990. Transcrição e revisão do original a cargo de Giuseppe Croce e Antonella Pagano.

Leia-se:

Giovanni Levi

Entrevista realizada em Roma, em 16 de fevereiro de 1990. Com pauta preparada por Guido Crainz, Gino Massullo e Giacomina Nenci, foi publicada no número 10 de Meridiana, em 1990. Transcrição e revisão do original a cargo de Giuseppe Croce e Antonella Pagano. ${ }^{1}$

Na página 182, onde se lia:

1 Original disponível em: http://www.rivistameridiana.it/files/Intervista-a-Giovanni-Levi.pdf. Os tradutores agradecem a Henrique Espada Lima Filho, Verónica Secreto e Laura de Oliveira. A publicação desta tradução foi autorizada tanto por Giovanni Levi quanto por Rocco Sciarrone, codiretor de Meridiana, aos quais também agradecemos.

Leia-se:

1 Original disponível em: http://www.rivistameridiana.it/files/Intervista-a-Giovanni-Levi. pdf. Tradução: Antonio Luigi Negro e Jonas Brito. Os tradutores agradecem a Henrique Espada Lima Filho, Verónica Secreto e Laura de Oliveira. A publicação desta tradução foi autorizada tanto por Giovanni Levi quanto por Rocco Sciarrone, codiretor de Meridiana, aos quais também agradecemos. 